IMAGE CHALLENGE

\section{A 69-year-old woman with extended negative T wave}

\section{CLINICAL INTRODUCTION}

A 69-year-old woman with hypertension and dyslipidemia developed sudden onset of substernal chest pain at night and was admitted to our hospital the following day. A 12-lead and 18-lead ECG (Nihon Kohden, Japan) was done (figure 1A,B).

\section{QUESTION}

Which is the most likely diagnosis?

A. Reperfused anterior acute myocardial infarction

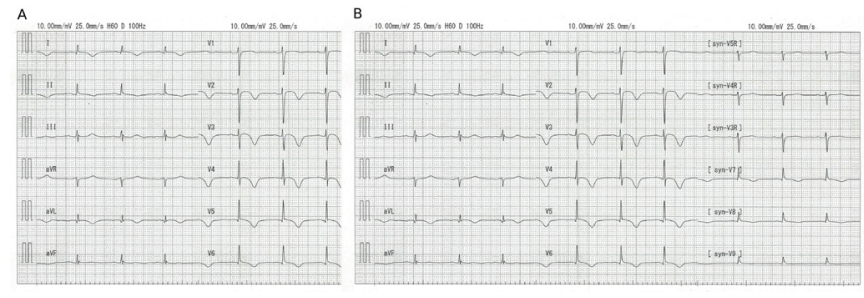

Figure 1 (A) Twelve-lead ECG. (B) Eighteen-lead ECG.

B. Takotsubo (stressed) cardiomyopathy

C. Pericarditis

D. Apical hypertrophic cardiomyopathy

For answer see page 584 
IMAGE CHALLENGE

\section{A 69-year-old woman with extended negative T wave}

For question see page 561

\section{ANSWER \\ B. Takotsubo (stress) cardiomyopathy}

Extended negative $\mathrm{T}$ waves in a 12-lead ECG can be found in patients with acute myocardial infarction (AMI), Takotsubo cardiomyopathy, pericarditis and apical hypertrophic cardiomyopathy. In this patient, pericarditis was unlikely because there was no ST-segment elevation or PR-segment depression. ${ }^{1}$ Hypertrophic cardiomyopathy was also unlikely because of the prolonged QT interval ${ }^{2}$ and the lack of negative $\mathrm{T}$ waves with a strain pattern. However, it was challenging to differentiate an AMI from a Takotsubo cardiomyopathy with a 12-lead ECG.

Negative T wave locations in an 18-lead ECG provide the critical clue to differentiate between the two diseases. ${ }^{3}$ Negative $\mathrm{T}$ waves in precordial (V1, V2, V3, V4), inferior (especially in II) and posterolateral (V6, syn-V7, syn-V8 and syn-V9) leads reflect pathological conditions of the anterior, inferior and posterolateral myocardium the possibility of a Takotsubo cardiomyopathy should be strongly considered because simultaneous changes in these leads in an AMI is extremely rare.

\section{Keiji Matsunaga ๑ , Takahisa Noma, Tetsuo Minamino}

Cardiorenal and Cerebrovascular Medicine, Faculty of Medicine Kagawa University, Kida-gun, Kagawa, Japan

Correspondence to Dr Tetsuo Minamino, Cardiorenal and Cerebrovascular Medicine, Kagawa University, Kida-gun, Kagawa, Japan; minamino@med.kagawa-u.ac.jp

Contributors All authors have contributed to the conception of the paper and the interpretation of the data.
Funding The authors have not declared a specific grant for this research from any funding agency in the public, commercial or not-for-profit sectors.

Competing interests None declared.

Patient consent for publication Not required.

Provenance and peer review Not commissioned; internally peer reviewed.

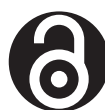

\section{OPEN ACCESS}

Open access This is an open access article distributed in accordance with the Creative Commons Attribution Non Commercial (CC BY-NC 4.0) license, which permits others to distribute, remix, adapt, build upon this work non-commercially, and license their derivative works on different terms, provided the original work is properly cited, appropriate credit is given, any changes made indicated, and the use is non-commercial. See: http://creativecommons.org/licenses/by-nc/4.0/.

(C) Author(s) (or their employer(s)) 2020. Re-use permitted under CC BY-NC. No commercial re-use. See rights and permissions. Published by BMJ.

\section{Check for updates}

To cite Matsunaga K, Noma T, Minamino T. Emerg Med J 2020;37:584.

Accepted 25 October 2019

Published Online First 28 November 2019

Emerg Med J 2020;37:584.

doi:10.1136/emermed-2019-208715

ORCID iD

Keiji Matsunaga http://orcid.org/0000-0003-3611-1143

\section{REFERENCES}

1 LeWinter MM. Acute pericarditis. N Eng/ J Med Overseas Ed 2014;371:2410-6.

2 Kosuge M, Ebina T, Hibi K, et al. Differences in negative T waves between takotsubo cardiomyopathy and reperfused anterior acute myocardial infarction. Circ J 2012;76:462-8.

3 Ashida T, Tani S, Nagao K, et al. Usefulness of synthesized 18-lead electrocardiography in the diagnosis of ST-elevation myocardial infarction: a pilot study. Am J Emerg Med 2017;35:448-57. 